\begin{tabular}{|c|c|}
\hline & $\begin{array}{l}\text { International Journal of Trend in Scientific } \\
\text { Research and Development (IJTSRD) }\end{array}$ \\
\hline 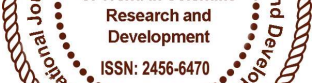 & International Open Access Journal \\
\hline 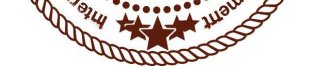 & ISSN No: 2456 - 6470 | www.ijtsrd.com | Volume - 2 | Issue - 2 \\
\hline
\end{tabular}

\title{
Effect of International Financial Reporting Standard on Corporate Performance of Selected Banks Listed on Nigeria Stock Exchange
}

\author{
Elosiuba, J. N. \\ Department of Accountancy, \\ Chukwuemeka Odumegwu Ojukwu University, \\ Anambra State, Nigeria
}

\author{
Prof. Emma Okoye \\ Department of Accountancy, \\ Nnamdi Azikiwe University, \\ Awka, Anambra State, Nigeria
}

\section{ABSTRACT}

In the light of globalisation where foreign investment has become trendy, comparability of financial reports of Nigerian firms and those of other firms across the world has become a concern. Nigerian firms have been mandated to adopt the International Financial Reporting Standard (IFRS) is their financial reporting. This study has examined the effect of the IFRS adoption on the reported performance of Nigerian banks listed on the Nigerian Stock Exchange. Eight (8) out of the fourteen (14) quoted banks were selected for the study. Four indices of performance employed in the study are profitability using the Return on Equity, Liquidity using total deposit to total loan, loan grants and then market value measured by Price earnings ratio for the period (2011 and 2012). 2011 represented GAAP era while 2012 stands for IFRS adoption. Comparability indexes for the banks were computed using the Excel Spreadsheet for each of the banks on each variable. Then the One Sample Test was employed for the analyses. The mean was used to answer the research question while the tstatistics tested the hypotheses. The results showed that mean values for profitability, liquidity and market value are greater in the GAAP era (2011) than in the IFRS period (2012), while loan grant has higher for IFRS period (2012). The t-tested indicated none of the variables had significant effect. Thus the study concluded that IFRS adopted does not have significant effect on bank performance reported in 2011 and 2012. The use of IFRS for all firms as well as incorporation of IFRS guideline in professional training are recommended by this study.

Keywords: International Financial Reporting Standards, (IFRS), Generally Accepted Accounting Practice (GAAP), corporate performance, Nigeria

JEL Classification: G32, M41

\section{INTRODUCTION}

\subsection{Background to the Study}

The widespread adoption of International Financial Reporting Standards (IFRS) indicated a new era in financial reporting (Taiwo \& Adejare, 2014). Considering the relative newness of the presence of International Financial Reporting Standard (IFRS) in Nigeria and other sub Saharan Africa, its adoption has not been taken seriously (Abata, 2015a). Ismaila, (2010) stressed that only about $20 \%$ of the 54 countries in Africa have adopted IFRSs as a principle based financial reporting structure. This conforms their ignorance of the benefits which IFRSs can bring to a more transparent and credible financial reporting practice or their unwillingness to be part of the global economy (Abata, 2015a).

It will be in the interest of the Nigerian economy for listed companies to adopt globally accepted, high quality accounting standards, by fully converging 
Nigerian national accounting standards with International Financial Reporting Standards (IFRS) over the earliest possible transition period, given the increasing globalization of capital markets (IFRS) Adoption Roadmap Committee, 2010). According to the IFRS adoption Roadmap Committee (2010), Public Listed Entities and Significant Public Interest Entities are expected to adopt the IFRS by January 2012. All Other Public Interest Entities are expected to mandatorily adopt the IFRS for statutory purposes by January 2013, and Small and Medium-sized Entities (SMEs) shall mandatorily adopt IFRS by January 2014.

The financial wellbeing of any business entity plays a vital role in the wellbeing of stakeholders and the country at large (Sofia, 2015). In this era of global economic meltdown, there is an urgent need for corporate entities in Nigeria to improve their corporate performance to be and remain relevant in the global market (Ironkwe \& Oglekwu, 2016). Full compliance to International Financial Reporting Standards (IFRS) plays a vital role in increasing and improving the acceptability and reliability of the instrument used in measuring corporate performance of a given business entity (Ofurum, Egbe \& Micah, 2014). The corporate performance is of paramount concern to shareholders, management, employees, investors, creditors, tax authority etc which have different interest in the organization. Their various performance interests focus ranges from profitability, solvency, and efficiency to capital structure performance (Frank and Alan, 2008). Corporate performance can be measured through the analysis and interpretation of the components that make up the financial statements.

Controversies always existed over the suitability of applying IFRS in developing countries with Singh and Newberry (2008) and Chen, Jiang and Lin (2010) arguing that there exist two schools of thought in this area. The first supports a single set of global standards as being suitable for application. Barth, (2008), for instance, argues that by adopting a common body of international standards, countries can expect to lower the cost of information processing and auditors of financial reports can be expected to become familiar with one common set of international accounting standards than with various local accounting standards. The second opposes the use of IFRS. Barth, Landsman and Lang (2007) and Bartov, Goldberg and Kim (2005) argue that there is no conclusive evidence that IFRS have contributed to improvements in accounting quality. Furthermore, it has been argued that one single set of accounting standards cannot reflect the differences in national business practices arising from differences in institutions and cultures (Armstrong, Barth, Jagolinzer, \& Riedl, 2007; Access Bank, 2010).

According to Ofurum, Egbe and Micahn (2014), all Listed Companies in Nigeria which banks are among are mandated to adopt IFRS by January 1, 2012 and by 2015 there should be full compliance of all business categories. From the foregoing, the focus of this research is to examine whether there is increase in indicators of corporate performance of these companies that have adopted IFRS as a principle in which their financial statement is being prepared and presented. The corporate performance of an organization is of great interest to stakeholders who want to determine beforehand the earnings per share and return on equity of such organization before investing their limited scare resources. IFRS adoption gives confidence to stakeholders in relying on the financial statements to take relevant and informed decisions. IFRS is viewed as international financial reporting standards with high quality principles that is recognized and accepted globally by companies around the world. In light of this therefore, this study focuses on the effect IFRS has on selected indicators of corporate performance of Listed Banks in Nigeria. That is, in what way has the compliance to IFRS help to increase, profits, liquidity, loan grants and market value which is the main reason for any organization been in existence.

\subsection{Statement of the Problem}

Scholars have argued that the characteristics of local business environments and institutional frameworks determine the form and contents of accounting standards in developing countries. Developing countries which Nigeria is inclusive are characterized by delicate institutions and unstable economic and political environments which are not beneficial to assimilation of IFRS (Muhammad, 2015). Regardless of the arguments, several countries and companies have adopted IFRS and there is irresistible need to review the outcome. There are mixed results as to whether the adoption of the IFRS improves the performance of business institutions or not (Muhammad, 2015). Lantto and Sahlström (2009) for instance, present such results as the adoption of IFRS 
affects financial ratios of firms in Finland. They found that liquidity ratios decrease under IFRS, while leverage and profitability ratios increase.

As evident from the foregoing, a good number of studies carried out in different countries have highlighted the benefits of having single set of financial reporting standards across the globe in supporting the adoption of IFRS globally. Few of the studies had given contradictory views questioning the relevance of IFRS adoption in developing and emerging economies (Mutai, 2014). The fact that financial reports exist to satisfy the diverse needs of numerous users such as the investors, management, employees, government, researchers, and so on, there is need to evaluate its overwhelming impact. The problem is that banks have incentives to withhold or manipulate information in certain situations (poor performance). This is because the publication of such information imposes both direct and indirect cost on the disclosing firm (Mutai, 2014). Besides the cost of collating, processing, communicating and auditing the information to be published, the position of the disclosing firm may be damaged when such information is used by competitors, government agencies, trade unions, clients or suppliers.

In light of this therefore, this study focuses on the effect of IFRS on selected Banks in Nigeria. The study is said to determine if bank performance has improved since the adoption of IFRS in 2012.

\subsection{Objective of the Study}

The main objective of this study is to investigate the effect of IFRS on corporate performance of selected banks listed on Nigeria Stock Exchange. The specific objectives include:

1. To investigate the effect of IFRS adoption on the profitability of banks in Nigeria.

2. To determine the effect of IFRS adoption on the liquidity of banks in Nigeria.

3. To determine the effect of IFRS adoption on loan grants of banks in Nigeria.

4. To ascertain the effect of IFRS adoption on market value of banks in Nigeria.

\section{REVIEW OF RELATED LITERATURE}

\subsection{Conceptual Framework}

\subsubsection{Concept of International Financial Reporting Standards (IFRS)}

International Financial Reporting Standards (IFRS) are a set of accounting standards developed by the International Accounting Standards Board (IASB) that is becoming the global standard for the preparation of public company financial statements. According to Nobes (2006), the term International Accounting Standards convergence is not a new agreement; the thought originally came up during the later part of 1950, in response to post World War II economic and financial integration and the associated enhancement in capital flow across borders. Prior to this time, efforts were geared towards Harmonization of Accounting Standards. This simply means decreasing dissimilarity in accounting concepts and principles adopted in most capital markets in nations around the world. The concept of Convergence in the 1990s replaces Harmonization which simply means the creation of international accounting standards that is of excellent quality to be employed in almost all the major capital markets of the world.

This unified set of Accounting Principles was brought into reality to trim line the international differences that restrained investment opportunities worldwide (IFAC, 2008). In view of the fact that one's environment affects the way and manner Accounting is being practice, this perceived cultural factor of such environment comprises their individual belief system and the value they uphold; the Accountants' value system is also determines by the Cultural Environment prevalent in that country. Further contributing factors to International Accounting Standards differences are taxation method, legal system and inflation of that geographical region. The International Accounting Standards Committee (IASC) as a body was created to bridge the gap of International Accounting Standards differences. In 1973, IASC was established by professional accountancy bodies from ten different nations, which include United Kingdom, Australia, Ireland, Canada, Germany, Mexico, France, Netherlands, Japan and the United States of America. The task of this body is to formulate and publish Accounting Standards that is of public interest; which are to be followed to ensure that audited accounts and financial statements are prepared, presented and reported in order to encourage global approval. In April 1, 2001, IASC and FASB (Financial Accounting Standards Board) held a meeting which gave convergence a fresh drive. Ever since then the drive in the direction to International Accounting Standards has advanced speedily and in the year 2009, European Union and 
more than 130 nations of the world have either permitted or required the adoption of IFRS published by the IASB or the local variation of the Board.

\subsubsection{International Financial Reporting Standard (IFRS) in Nigeria}

The Federal Government of Nigeria on 2nd September 2010 officially declares IFRS adoption in Nigeria and initiated the guidelines to be followed for its accomplishment. The consent to IFRS adoption by the Federal Government of Nigeria made the country becomes enlisted member of those countries that have adopted IFRS across the globe. The guiding principles to be followed for implementing IFRS are in three consecutive phases. The first phase comprises of Listed and Significant Public Interest Entities that are mandate to prepare and present their audited financial statements in compliance to relevant IFRS by $31 \mathrm{st}$ December, 2012. The second phase of IFRS implementation focuses on Public Interest Entities that are authorized to comply with IFRS format for statutory rationale by 31 st December, 2013. The third phase on the other hand, expects all Small and Medium sized Enterprises (SMEs) to mandatorily comply with the adoption of IFRS as statutory reporting by 31 st December 2014 (Uwadiae, 2012).

As a universally accepted fact, Accounting is seen as the language of business through which performance and position of an entity is being communicated to outsiders (stakeholders) need to be spoken in a common language. IFRS has made this statement a reality because through the acceptance of IFRS, business language can be spoken in a language which is universally known, accepted, and understood by almost all worldwide investors.

Adejoh and Hasnah (2014) noted that the need for a high quality and a uniform manner for which financial statements is being prepared and presented gave rise to IFRS. IFRS as a principle based format is seen as a set of published financial accounting pronouncements given by the IASB to assist Accountants and Auditors across the world in the preparation, presentation and reporting of transparent, high quality and comparable financial information to aid informed decision making.

IFRS according to Siti et al. (2014) is common global language designed to be followed by companies across international boundaries to reflect its financial activities and to improve the understanding, comparability and quality of financial reporting. Chakrabarty (2011) is of the opinion that IFRS as a standard are meant to attain these objectives; support in the standardization of the varied accounting principles and policies obtainable across the globe and enhancing comparability of financial statements. To also facilitate the preparation and presentation financial statements that is transparent, comparable of high quality information. Furthermore, the objective is meant to reduce alternatives ways of preparing Financial Statements and thereby eliminate the element of subjectivity.

\subsection{Theoretical Framework}

This work is anchored on Michael C. Jensen (2001) Value Maximization theory.The fundamental reason of firm's Financial Statement being disclosure in compliance with IFRS is to maximize firm's value at the long run.this theory states that the primary objective and purpose of a firm being in existence is to get the most out of shareholders wealth, which is maximize shareholders wealth in the long run (AbdulBaki, Uthman, \& Sanni, 2014). According to him, this theory explains that all the activities of an organization whether charitable or otherwise, is basically seeking to make profit. This theory also states that at the long run, there will be maximization of other stakeholders and financial claimants like debt and warrant holders (Abdul-Baki, Uthman, \& Sanni, 2014) The Researcher therefore noted that the fundamental reason or essence of a firm's Financial Statement being disclosure in compliance with IFRS is to maximize mangers' and firm's value at the long run.

\subsection{Empirical Review}

Ironkwe and Oglekwu (2016) carried out a study on International Financial Reporting Standards (IFRSs) and Corporate Performance of Listed Companies in Nigeria. The study adopted personal interview and questionnaire methods as the major techniques for primary data collection. Data collected were analyzed using both descriptive such as tables, frequencies and percentages and inferential statistics of Chi-square and ANOVA respectively. The study concluded that that there is a strong positive relationship between the adoption of IFRS and financial performance due to cost reduction of an organisation. IFRS adoption improves business efficiency and productivity for effective business performance. The adoption of IFRS saves Multinational Corporations the expense of preparing more than one set of accounts for different national jurisdictions. 
Abata (2015b) carried out an investigative study on the impact of IFRS on Financial Reporting Practices in Nigeria. Data were collected from 50 employees of KPMG (a leading professional financial services provider) through the use of structured questionnaire and analysed using mean scores, standard deviation and Pearson Chi-square analysis. The findings revealed that IFRS provides better information for regulators than GAAP (mean $=4.72$ ). The results of the study showed that changes in business processes and operations, financial position of companies and reduction in cost of finance were the least contributions of IFRS to financial reporting practices of KPMG. The results of Pearson Chi-square analysis showed that financial reports prepared under IFRSs enhanced best practices in a corporate organization (Pearson Chi-Square $=37.857$ ); financial statements prepared in line with IFRS provides greater benefits than the former GAAP (SAS) (Pearson Chi-Square $=$ 75.763); the compliance with IFRS promotes cross border investment and access to (Pearson Chi-Square $=63.128$ ); and compliance with IFRS will relatively improve the performance of companies (Pearson ChiSquare $=20.417$ ).

Shehu (2015) researched on adoption of international financial reporting standards and earnings quality in listed deposit money banks in Nigeria. It investigates firm attributes from the perspective of structure, monitoring, performance elements and the quality of earnings of listed deposit money banks in Nigeria. The study adopted correlational research design with balanced panel data of 14 banks as sample of the study using multiple regression as a tool of analysis. The result reveals that firms attributes (leverage, profitability, liquidity, bank size and bank growth) has as significant influence on earnings quality of listed deposit money banks in Nigeria after the adoption of IFRS, while the pre period shows that the selected firm attributes has no significant impact on earnings quality. It is therefore concluded that the adoption of IFRS is right and timely.

Abata (2015a) studied the impact of International Financial Reporting Standards (IFRS) adoption on financial reporting practice in the Nigerian banking sector. The specific objective of this paper is to determine whether the quantitative differences in the financial reports prepared by Nigerian listed banks under NGAAP and IAS/IFRS are statistically significant or not. Secondary data were employed in this study. These data were gleaned from the annual reports of fourteen Nigerian listed banks. One hypothesis was developed and tested at five (5) per cent level of significance. Findings revealed that the quantitative differences in the financial reports prepared under NGAAP and IAS/IFRS are statistically significant. The study therefore concludes that IFRS have impacted on financial reporting in the Nigerian Banking sector.

Muhammad (2012) examined the effect of International Financial Reporting Standards (IFRS) adoption on the performance of firms in Nigeria. The study utilizes secondary data to tests the effects of the adoption of IFRS on the performance of the selected firms in Nigeria. Logit regression and t-test were used in the analysis. The study finds that variability of earnings has decreased from an average of 32624.4 to 14432.2 which suggest that there was low variability in earnings in the post adoption period. Timely loss recognition is the measure for prevalence of large negative earnings where large negative results suggest that the loss recognition is not timely in the post adoption period. He found LNEG to be positive which signifies that IFRS firms recognize losses more frequently in the post adoption period than they do in the pre adoption period. The study therefore conclude that accounting quality improves after the adoption of IFRS. Furthermore, under IFRS firms tend to exhibit higher values on a number of profitability measures, such as earnings per share (EPS).

Kaaya (2015) investigated the impact of International Financial Reporting Standards (IFRS) on earnings management. The study applies a desktop review to investigate the worldwide existing empirical research evidence on the impact of IFRS on earnings management post- IFRS adoption and in relation to other reporting standards and reports whether the results are indistinguishable between developed and developing economies. The findings reveal that the existing empirical crams and conclusions there on are mixed, inconsistent and difficult to generalise. This indicates the pressing need for country specific empirically tested studies of this nature. The study further, stumbles on the fact that IFRS can indistinctly benefit both developing and developed markets when coupled with appropriate effective enforcement machinery. Substantially, the results entail that IFRS is a critical determinant for quality reporting but not a 'prima facie' guarantor for quality reporting. 
Sani and Umar (2014) assessed the extent to which the Nigerian Banking Industry complied with these requirements as captured in IFRS 1: First Time Adoption of IFRS. Using ex-post facto and survey research designs, the study sourced data from structured questionnaire and recent audited financial reports of the sampled banks. Qualitative Grading System (QGS) was employed in determining the degree of compliance of the banks while Multivariate regression and Chi-squire test were used in measuring the effect of the factors responsible of such compliance and identified probable difficulties in the process respectively. The study concludes that, Nigerian banking industry complied (semi-strongly) with the requirements of IFRS-framework but, the exercise is still faced with some challenges which include: lack of indepth IFRS knowledge from the preparers of the financial reports. The study also found amenability, globalization and response to users' needs as factors significantly influencing the compliance level of Nigerian banks with IFRSframework.

Eneje, Obidike \& Chukwujekwu (2016) examined the effect of IFRS adoption on the mechanics of loan loss provisioning for Nigerian Banks. They analyses how the change in the recognition and measurement of loan loss provision affects the accounting quality of banks thereby reducing the income smoothing behavior of the money deposit banks. In the model specified, loan loss provision for the current year was used as the dependent variable while non-performing loans at the beginning of the year, current changes in non-performing loans, current changes in total loans, earnings before taxes and loan loss provisions alongside with IFRS*Ebtllp were used as the independent variables. In line with the objectives of this study, secondary data were obtained from the deposit money banks annual reports and accounts covering the period of 2005 to 2015. Descriptive statistics and the ordinary least square multiple regression analytical method was used for the data analysis. It was found that the limitation to recognize only incurred losses under IAS 39 significantly reduces income smoothing and delay recognition of future expected losses.Based on the sampled bank dataset and results, this paper has shown that the postIFRS has had significant effects on the mechanics of loan loss provisioning compared to the pre-IFRS era in the Nigerian Money Deposit Banks.
Ugbede, Mohd and Ahmad (2014) investigated International Financial Reporting Standards and the quality of banks financial statement information: evidence from an emerging market-Nigeria. The study measures quality of financial statement information using earnings management, timeliness of loss recognition and value relevance. A total of twenty Nigeria banks covering a period of six years were investigated. Results suggest that IFRS adoption is associated with minimal earnings management and timely recognition of losses. Results marginally support IFRS adoption association with high value relevance of accounting information. Value relevance results were induced by capital market fraud. This study concludes that IFRS adoption engenders higher quality of banks financial statement information compared to local GAAP.

Kenneth, (2012) on Adoption of IFRS and Financial Statements Effects: The Perceived Implications on FDI and Nigeria Economy. He stated that the IFRS adoption is already an issue of global relevance among various countries of the world due to the quest for uniformity, reliability and comparability of financial statements of companies. The paper however investigated the effect of IFRS adoption on Foreign Direct Investment and Nigeria economy. The population used consists of quoted companies in Nigeria Stock Exchange (Preparers) and Investment Analysts (Users). Stratified Random sampling method was adopted and primary data used to elicit responses with 123 structured questionnaires administered. Findings showed that IFRS has been adopted in Nigeria but only fraction of companies has implemented with deadline for the others to comply. It is perceived that IFRS implementation will promote FDI inflows and economic growth. It was recommended that all stakeholders should endeavour to have full implementation to reap benefits of the global GAAP and principle - based standards.

In trying to elicit the opinion of stakeholders in financial reporting in Nigeria, regarding the necessity for the ongoing mandatory adoption of IFRS in Nigeria, Isenmila and Adeyemo, (2013) on "A Perception Based Analysis of the Mandatory Adoption of (IFRS) in Nigeria" adopt the questionnaire survey method to seek respondents' views on the subject matter. Understanding firms' adoption of IFRS can allow for insights into the benefits and costs colligated with such adoption. Specifically, the study expected to be of significance 
to Equity Investors' Group, Governments and Regulators, National standard setter, International Standards Setters and Donor Agencies, and various organizations engaged in accounting processes. The paper therefore employed the One Way Repeated Measure Analysis of Variance, and the Likelihood Ratio Test, otherwise referred to as G-test or maximum likelihood statistical significance test, in resolving the three hypotheses in the paper. The results show that there is a statistically significant difference in the perception of the stakeholders about the desirability of the mandatory adoption of IFRS. The stakeholders of interest were Preparers of Financial Reports, Auditors, Capital Market Operators, and Trainers of accounting students. Capital Market Operators was found to be the most optimistic about the success of the adoption of IFRS, while Auditors seem to be the least optimistic. Additionally we found that mandatory adoption of IFRS will have significant prospects as well as challenges on the activities of stakeholders. We recommended inter alia, that the capacity of regulators (Corporate Affairs Commission, Securities and Exchange Commission, National Insurance Commission, Central Bank of Nigeria to mention but a few) must be strengthened so as to enable them to effectively deal with accounting and financial reporting practices of the regulated concerns, so that the mandatory adoption of IFRS in Nigeria, does not become a mere labeled or nominal one.

On the paper of Afego (2011) on the Stock Price Response to Earnings Announcements: Evidence from the Nigerian Stock Market, This paper examines the stock market reaction to annual earnings information releases using data on the Nigerian Stock Exchange. Using the event study method, the speed of reaction of the market to annual earnings information releases for a sample of 16 firms listed on the exchange is tested. Significant abnormal price reactions around earnings announcements suggest the earnings announcements contain value-relevant information. The paper find that the magnitude of the cumulative abnormal returns is dominated by significant reactions 20 days before the earnings release date which suggests that a portion of the market reaction may be due to private acquisition and, possibly, abuse of information by insiders. The persistent downward drift of the cumulative abnormal returns, 20 days after the announcement, is inconsistent with the efficient markets hypothesis, and therefore suggests that the Nigerian stock market does not efficiently adjust to earnings information for the sample firms within the study period.

On the study of Ajao and Wemambu (2012) on Volatility Estimation and Stock Price Prediction in the Nigerian Stock Market. The study aimed at understanding the Nigerian Stock Market with regards to volatility and prediction, to this effect the month end stock prices of four major companies from the period January 2005 to December, 2009 was used as proxy. The study made use of the Autoregressive Conditional Heteroskedasticity (ARCH) to estimate and find out the presence of volatility. According to the study the presence of volatility in all the four stock prices used, while stock price volatility was then regressed against stock prices to determine their predictability. The results however, revealed that out of the four companies, only two companies' stock prices were predicted by volatility in their stock prices, while past stock prices predicted current stock prices implying that the market does not follow a random walk. As a result of these, it is recommended that activities of corporate insiders should be properly checked, to reduce the predictability of stock prices, information should be known and made public to all investors. Also policy makers are advised to review their economic policies and should be careful in their use of the Nigerian bourse as a barometer to reflect performance in the general economy as our findings suggests that this could be misleading.

Asian and Dike (2015) investigates the differences in the quality of accounting information Pre and post IFRS adoption by manufacturing firms in Nigeria over a five year period. Multiple regression analysis was performed on accounting quality variables and $t$ test was carried out for equality of mean to compare pre and post IFRS. Results indicate a decline in accounting quality using earnings management, value relevance, and timely loss recognition as independent variables. Earnings and book value of equity are less value relevant and timely loss recognition is less in post-IFRS compared to pre-IFRS period.

Okoye, Okoye and Ezejiofor (2014) assess the impact of International Financial Reporting Standard on stock market movement and to extent at which it can improve the position of corporate organization in Nigerian capital market. Descriptive design was adopted using the stock price and shares traded during two years periods. SPSS Version 7.0 were also used to obtain the mean, variance and Std. Deviation. It 
observed that the adoption of IFRS in Nigeria will enhance credible financial statements that will also provide a basis for the strength of a corporate entity in capital market hence is a welcome development in Nigerian economy.

Nengzih (2015) examine the impact of the adoption of IFRS on profitability rate and tax income for before and after IFRS adoption in Indonesia Listed Company. By using paired samples t-test, using SPSS 20.0. Results form in descriptive statistics analysis and hypotheses testing. Results show that the average ratio of companies' profitability is increasing after the adoption of IFRS. The profitability results also show that there is no change in the amount of profit before tax after the adoption of IFRS. IFRS is a set of standards in principles-based that needs full reasoning, clear judgment and deep understanding from its user. Lack of understanding and judgment will indicates that managers have bigger flexibility. Business environment and a fundamentally different situation also determine the form and content of accounting standards. This research is able to give a new paradigm in the adoption of IFRS that needs a comprehensive understanding for its user.

Upon the adoption of IFRS in 2012, researchers were keen to find out the Economic Consequences of this move. With the quest for the impact of IFRS on the Nigerian Economy, Wilson and Ioraver (2013) investigated the Economic Consequences of IFRS adoption: Evidence from a developing country. Their results showed that there is deficiency in experience, tutoring and apprehension of financial report preparers on how to bring into play IFRS format and absent of IFRS treatment in Auditing and Financial Accounting text books. They also suggested the pressing need to integrate IFRS into the curriculum of Accounting Student of higher learning. It as well calls for the attention of Financial Regulator and accounting professional bodies to keep informed in their IFRS's knowledge so as to sustain its professional proficiency.

Ezeani and Oladele (2012) carried out a research on the Adoption of IFRS to Enhance Financial Reporting in Nigerian. The fundamental reason of accepting this uniform standard in preparing and presenting Financial Statement is for Nigerian Economy to fit into International Best Practice of the world in terms of Financial Reporting. They found out that there is a great deal of accounting and financial areas Auditors and Accountants need to focus in dispatching their duties and responsibilities which has implications both positive and negative. One of their recommendations among many others is that syllabus of Nigerian Institution ought to be evaluated to include IFRS, so that Accounting graduates will be up to date with IFRS Standards and guidelines.

In 2014, Jonathan and Amos carried out a research on Stakeholders' Perception of the Implementation of IFRS in Nigeria. They found out that significance variation exist in the perception of Stakeholders concerning the working of IFRS in the worth of Financial Report. There is no considerable discrepancy in their perception about the implementation of IFRS with the improvement of quality of investment decision and assessing the bases of Return on Investment. They recommended that relevant Authorities should make sure that organization comply with IFRS to ensure that Audit Report reflect the genuine position of the entity's financial circumstance. They also opined that government should strengthen the Financial Reporting Council of Nigeria with qualified personnel in order to satisfactorily perform its functions.

Akinleye (2016) examined the effect of international financial reporting standards (IFRS) adoption on the performance of money deposit banks in Nigeria. The study employed ratio analysis to investigate the nexus between IFRS adoption and performance of money deposit banks in the Nigeria. Data used in the study were sourced from the financial statements of the selected banks for the period under study. Panel data analysis in the form of pooled OLS analysis, fixed effect analysis and random effect analysis alongside post estimation test such as restricted f-test and Hausman test were used. The results revealed that adoption of IFRS exert positive impact on performance of money deposit banks measured in terms of return on assets $(\beta=0.9057884, \mathrm{P}=0.347)$ and in terms of return on equity $(\beta=0.0655296, \mathrm{P}=0.975)$.

Muhibudeen (2015) investigated International Financial Reporting Standard and Value Relevance of Accounting Information in Quoted Cement Firms in Nigeria. This study empirically examines whether the mandatory adoption of IFRS has improved the value relevance of financial information in the financial statements of quoted cement companies in Nigeria. Descriptive statistics and regression were conducted to analyze the effect of IFRS adoption on the accounting information quality using Stata version 
12.The study finds that the earning per share, book value of equity and share prices of Cement Company have significantly improved following IFRS adoption, although earnings per share proved more significant compared to book value of equity.

Yahaya, Yusuf and Dania (2015) examined International Financial Reporting Standards' Adoption and Financial Statement Effects: Evidence from Listed Deposit Money Banks in Nigeria. The objective of the paper is to examine the effects on financial statement of the adoption of IFRS in Nigeria and the impact of IFRS adoption. The empirical analysis used the binary logistic regression analysis. The results show that IFRS adoption has positively impacted some variables in the financial statement of banks, for example, profitability and growth potential. The paper also reveals that given the fair value perspective of IFRS, the transition to IFRS brings instability in income statement figures.

Adebimpe and Ekwere (2015) studied IFRS Adoption and Value Relevance of Financial Statements of Nigerian Listed Banks. The study empirically examines whether the mandatory adoption of IFRS has improved the value relevance of financial information in the financial statements of commercial banks in Nigeria. Descriptive statistics and least square regression were conducted to analyse the effect of IFRS adoption on the accounting quality. The result indicates that the equity value and earnings of banks are relatively value relevant to share prices under IFRS than under the previous Nigerian SAS.

\subsection{Gap in Literature}

Many search work have been carried out on IFRS but none of the works have covered what this research work intend to cover. Ironkwe and Oglekwu (2016) carried out research on the effect of International Financial Reporting Standards (IFRSs) on Corporate Performance. Muhammad (2012) examined the effect of International Financial Reporting Standards (IFRS) adoption on the performance of firms in Nigeria. Eneje, Obidike \& Chukwujekwu (2016) examined the effect of IFRS adoption on the mechanics of loan loss provisioning for Nigerian Banks. Ugbede, Mohd and Ahmad (2014) investigated International Financial Reporting Standards and the quality of banks financial statement information: evidence from an emerging market-Nigeria. Akiwi, (2010). The study aims at understanding the development of accounting in
Ghana and how accounting has evolved over the years. Okoye, Okoye and Ezejiofor (2014) assess the impact of International Financial Reporting Standard on stock market movement and to extent at which it can improve the position of corporate organization in Nigerian capital market. Among these studies, none have studies IFRS and bank performance, this study therefore will fill the gap by studying the effect of IFRS on the performance of banks in Nigeria.

\section{METHODOLOGY}

An Ex-Post Facto Design was adopted because the data used in this study is already in existence in the Nigerian Stock Exchange. Data were collected in areas such as Profits, Liquidity, Loan grants and Market value of banks listed in Nigeria Stock Exchange for the period under review.

The population for the study is all the 21 listed commercial banks (18 public limited liability companies and 3 government owned) that operate in Nigeria. A purposive sampling technique was used to select 8 banks that are listed on Nigeria Stock Exchange. The use of 8 banks is a suitable and fair sample since a sample of 0.05 proportion of the population is believed to be satisfactory in making inferences (Amadi, 2005). The study employed a sample of $38 \%$ of the total population of 21 banks. It is therefore a representative sample.

This study settled for only profitability, liquidity, loan grant and market value. The study tested some of the indicators of bank performance as outlined and explained below:

1. Profitability: This is computed using the Earnings Before Interests and Tax (EBIT) Return on Equity Ratio: $\frac{E B I T}{\text { Equity }} \times 100$.

It is represented by ROE

2. Liquidity Indicators: Loan to Deposit Ratio
(LDEP): $\frac{\text { Total Loan }}{\text { Total Deposits }}$

3. Loan grant indicators: The total loan grants per year

\section{Market Value Indicators:}

Price earnings ratio, abbreviated as $\mathrm{P} / \mathrm{E}$ is the best known used indicator and it is often used in regular stock news. It is considered the indicator of the total market assessment of the company. In a functioning market environment it provides estimate concerning 
the time needed for the price per share to be paid by its return.Price

earnings

ratio

$(\mathrm{P} / \mathrm{E})=\frac{\text { market value of a share }}{\text { earnings per share }}$

\subsection{Method of Analysis}

This study attempts to quantitatively measures the extent to which financial reports prepared under NGAAP and IFRS can be compared. To achieve this, a modified version of the Gray's Conservatism Index (Comparability Index) was used. Gray (1980, as cited in Cardozzo, 2008) first introduced the Index of Conservatism in comparing profits of several countries as a quantitative measure of differences between accounting practices. The study modified this Comparability Index by applying it to other key elements of financial statements such as Profitability, Liquidity, Loan Grant and Market Value prepared under NGAAP and IFRS. This Index is calculated below:

1. Total Comparability Index

$=1-\frac{\text { Profit }_{\text {IFRS }}-\text { Profit }_{\text {NGAAP }}}{\text { Profit }_{\text {IFRS }}}$

2. Total Comparability Index

$=81-\frac{\text { Liquidity }_{\text {IFRS }}-\text { Liquidity }_{\text {NGAAP }}}{\text { Liquidity }}$

3. Total Comparability Index

1- $\frac{\text { Loan Grant }_{\text {IFRS }} \text { - Loan Grant }}{\text { NGAAP }}$

4. Total Comparability Index

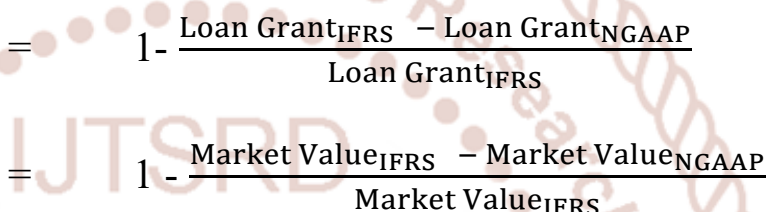

The yardstick used in this study is IFRS for evaluating the effects on the elements of the corporate performance of the transition from the Nigerian GAAP to IFRS. The profitability, liquidity, loan grant and market value reported under IFRS are chosen as the denominators in order to assess the effects of IFRS on corporate performance.

\section{Decision Rule}

The neutral value of the index is one. This implies a no effect situation on the GAAP by IFRS. An index that is greater than one implies that the Nigerian Banks' profitability, liquidity, loan grant and market value are higher during GAAP than what were reported under IFRS. Conversely, an index that is lower than one suggests that the Nigerian Banks' profitability, liquidity, loan grant and market value are lower during GAAP than that what were reported under IFRS. However the hypotheses are tested using the One Sample T-test computed with the help of the computer software called SPSS version 20.

\section{PRESENTATION AND ANALYSES OF DATA}

The analyses of the study was based on the Comparability Index of the Banks. The comparability indices on the variables are shown on Tables 1, 2, 3 and 4 for profitability, liquidity, loan and market value respectively.

Table 1: Computed Comparability Index of the Banks for Profitability

\begin{tabular}{lllll}
\hline Banks & GAAP Method & IFRS Method & Difference & $\begin{array}{l}\text { Comparability } \\
\text { Index }\end{array}$ \\
\cline { 2 - 3 } & $\begin{array}{l}2011 \\
\text { (N'000) }\end{array}$ & $\begin{array}{l}2012 \\
\text { (N'000) }\end{array}$ & & 0.48230668 \\
\hline Access Bank & 7.36 & 15.26 & 7.9 & 0.84991374 \\
Diamond Bank & 14.78 & 17.39 & 2.61 & 7.03529412 \\
Eco Bank & 23.92 & 3.40 & -20.52 & 0.04978123 \\
Fidelity Bank & 6.03 & 121.13 & 115.1 & 0.47006256 \\
First Bank Nigeria & 10.52 & 22.38 & 11.86 & -1.053135 \\
FCMB & -9.91 & 9.41 & 19.32 & 0.54709419 \\
UBA Plc & 13.65 & 24.95 & 11.3 & 0.71541686 \\
Zenith Bank Plc & 15.36 & 21.47 & 6.11 & \\
\hline
\end{tabular}


International Journal of Trend in Scientific Research and Development (IJTSRD) ISSN: 2456-6470

Table 2: Computed Comparability Index of the Banks for Liquidity

\begin{tabular}{lllll}
\hline Banks & GAAP Method & IFRS Method & Difference & $\begin{array}{l}\text { Comparability } \\
\text { Index }\end{array}$ \\
\cline { 2 - 3 } & $\begin{array}{l}2011 \\
\text { (N'000) }\end{array}$ & $\begin{array}{l}2012 \\
\text { (N'000) }\end{array}$ & & \\
\hline Access Bank & 88.62 & 143.62 & 55 & 0.61704498 \\
Diamond Bank & 62.72 & 62.96 & 0.24 & 0.99618806 \\
Eco Bank & 45.54 & 51.36 & 5.82 & 0.88668224 \\
Fidelity Bank & 45.49 & 33.01 & -12.48 & 1.37806725 \\
First Bank Nigeria & 62.34 & 60.10 & -2.24 & 1.03727121 \\
FCMB & 77.43 & 54.40 & -23.03 & 1.42334559 \\
UBA Plc & 41.12 & 46.71 & 5.59 & 0.88032541 \\
Zenith Bank Plc & 44.86 & 49.69 & 4.83 & 0.90279734 \\
\hline
\end{tabular}

Table 3: Computed Comparability Index of the Banks for Loan grant

\begin{tabular}{lllll}
\hline Banks & GAAP Method & IFRS Method & Difference & \multirow{2}{*}{ Comparability Index } \\
\cline { 2 - 3 } & $\begin{array}{l}2011 \\
\text { (N'000) }\end{array}$ & $\begin{array}{l}2012 \\
\text { (N'000) }\end{array}$ & & \\
\hline Access Bank & $217,634,811.00$ & $237,624,211.00$ & 19989400 & 0.9158781 \\
Diamond Bank & $344,397,331.00$ & $523,374,608.00$ & 178977277 & 0.65803217 \\
Eco Bank & $410,150.00$ & $546,873.00$ & 136723 & 0.74999131 \\
Fidelity Bank & $255,257.00$ & $152,257.00$ & -103000 & 1.67648778 \\
First Bank Nigeria & $1,144,461.00$ & $1,316,407.00$ & 171946 & 0.86938234 \\
FCMB & $319,020,875.00$ & $350,489,990.00$ & 31469115 & 0.91021394 \\
UBA Plc & $607,486.00$ & $795,254.00$ & 187768 & 0.76388927 \\
Zenith Bank Plc & $707,586.00$ & $895,354.00$ & 187768 & 0.7902863 \\
\hline
\end{tabular}

Table 4: Computed Comparability Index of the Banks for Market value

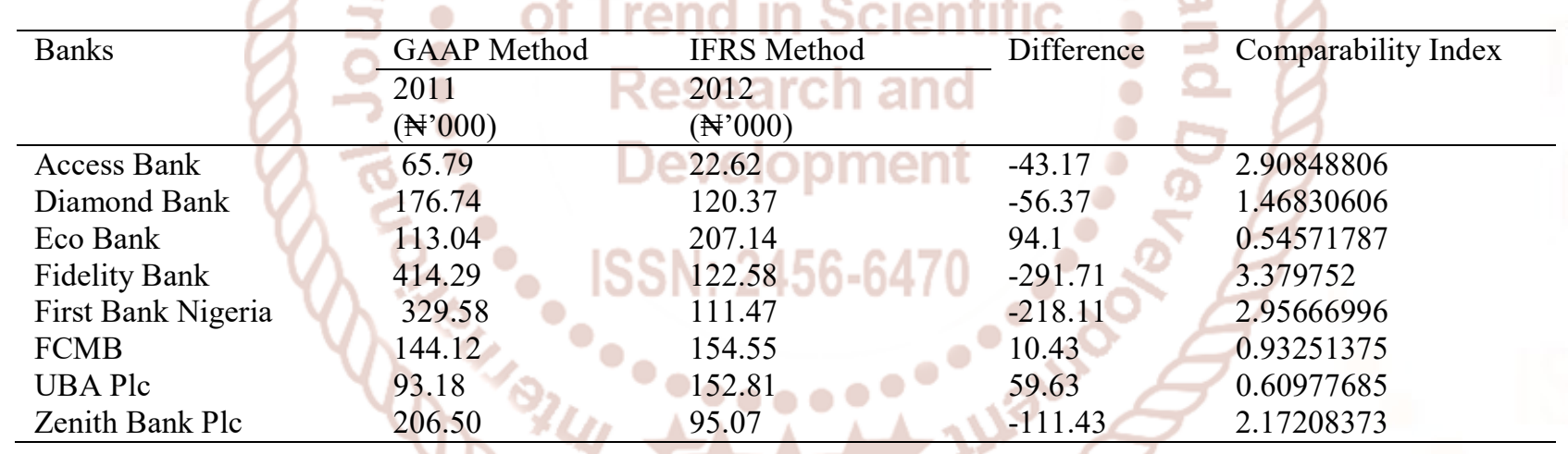

\section{Analyses of Objectives}

The mean comparability index was used in the next section to answer the research questions. In answering the research questions, we compare the value of the index to see whether it is equal to or greater than one. Results equal to one implies that there is no difference in the value and thus IFRS has no effect. However the group mean and standard deviation is employed to answer the research questions while the t-test tested the hypotheses from SPSS analyses.

The One Sample T-test statistics was employed. It aimed to test whether there is any significant difference in the mean value of the Comparability indices of the banks that participated in the study. The test is the difference between a sample mean and a known or hypothesized value. The group mean answered the research questions while t-statistics tested the hypotheses. 


\section{Effect of IFRS adoption affect profitability of banks}

Research One: To what extent does IFRS adoption affect profitability of banks in Nigeria?

Table 5: IFRS Adoption effect on profitability of banks

\section{One-Sample Statistics}

\begin{tabular}{|l|l|l|l|l|}
\hline & $\mathrm{N}$ & Mean & Std. Deviation & Std. Error Mean \\
\hline Index of Profitability & 8 & 1.1371 & 2.45677 & .86860 \\
\hline
\end{tabular}

The mean comparability index of 1.1371 suggests that profitability under IFRS are less than that of Nigerian GAAP for all the sampled eight banks. This means that the total profitability for all the banks under NGAAP is greater than that of IFRS. This implies that introduction of IFRS has negatively affected the profitability of the sampled banks.

Hypothesis One: IFRS adoption does not significantly affects profitability of banks in Nigeria.

Table 6: Significant Effect of IFRS Adoption on Profitability of Banks

\section{One-Sample Test}

\begin{tabular}{|c|c|c|c|c|c|c|}
\hline & \multicolumn{6}{|c|}{ Test Value $=1$} \\
\hline & \multirow[t]{2}{*}{$\mathrm{T}$} & \multirow[t]{2}{*}{ df } & \multirow[t]{2}{*}{ Sig. (2-tailed) } & \multicolumn{3}{|c|}{$\begin{array}{c}\text { Mean Difference } 95 \% \text { Confidence Interval of the } \\
\text { Difference }\end{array}$} \\
\hline & & & & & Lower & Upper \\
\hline Index of Profitability & .158 & 7 & 0.879 & .13709 & -1.9168 & 2.1910 \\
\hline
\end{tabular}

From table 6 , the probability value is 0.879 level of significance. Since the probability value is greater than 0.05 level of significance, the null hypothesis is not rejected. This implies that the null hypothesis that IFRS adoption does not significantly affects profitability of banks in Nigeria stands accepted.

\section{Effect of IFRS adoption affect liquidity of banks}

Research Two - To what extent does IFRS adoption affects liquidity of banks in Nigeria?

Table 7: IFRS Adoption effect on Liquidity of banks

\section{One-Sample Statistics}

\begin{tabular}{|l|l|l|l|l|}
\hline & $\mathrm{N}$ & Mean & Std. Deviation & Std. Error Mean \\
\hline Index of Liquidity & 8 & 1.0152 & .26859 & .09496 \\
\hline
\end{tabular}

The mean comparability index of 1.0152 suggests that liquidity under IFRS are less than that of Nigerian GAAP for all the sampled eight banks. This means that the total liquidity for all the banks under NGAAP is greater than that of IFRS. This implies that introduction of IFRS has negatively affected the liquidity of the sampled banks.

Hypothesis Two - IFRS adoption does not significantly affects liquidity of banks in Nigeria. 


\section{One-Sample Test}

\begin{tabular}{|c|c|c|c|c|c|c|}
\hline & \multicolumn{6}{|c|}{ Test Value $=1$} \\
\hline & \multirow[t]{2}{*}{$\mathrm{T}$} & \multirow[t]{2}{*}{ df } & \multirow[t]{2}{*}{ Sig. (2-tailed) } & \multirow[t]{2}{*}{$\begin{array}{l}\text { Mean } \\
\text { Difference }\end{array}$} & \multicolumn{2}{|c|}{$\begin{array}{l}95 \% \text { Confidence Interval of the } \\
\text { Difference }\end{array}$} \\
\hline & & & & & Lower & Upper \\
\hline Index of Liquidity & .160 & 7 & .877 & .01522 & -.2093 & .2398 \\
\hline
\end{tabular}

The result on Table 8 showed that the probability value is 0.877 . Since the probability value is greater than 0.05 adopted in this study, we cannot reject the null hypothesis that IFRS adoption does not significantly affects liquidity of banks in Nigeria.

\section{Effect of IFRS adoption affect loan grants of banks}

Research Three - To what extent does IFRS adoption affects loan grants of banks in Nigeria?

Table 9: IFRS Adoption effect on loan grants of banks

\section{One-Sample Statistics}

\begin{tabular}{|l|l|l|l|l|}
\hline & $\mathrm{N}$ & Mean & Std. Deviation & Std. Error Mean \\
\hline Index of Loan Grants & 8 & .9168 & .31928 & .11288 \\
\hline
\end{tabular}

Table 9 showed that comparability index of all the eight banks put together. The comparability index of loan grant for the sample banks are 0.9168. Since it is less than 1, it means that total loan grant under IFRS is greater than those of NGAAP. This suggests that IFRS brings about positive increase in total loan grants for the sampled banks.

Hypothesis Three - IFRS adoption does not significantly affects loan grants of banks in Nigeria.

Table 10: Significant Effect of IFRS Adoption on loan grants of Banks

\section{One-Sample Test}

\begin{tabular}{|c|c|c|c|c|c|c|}
\hline & \multicolumn{6}{|c|}{ Test Value $=1$} \\
\hline & \multirow[t]{2}{*}{$T$} & \multirow[t]{2}{*}{ Df } & \multirow[t]{2}{*}{ Sig. (2-tailed) } & \multirow[t]{2}{*}{$\begin{array}{l}\text { Mean } \\
\text { Difference }\end{array}$} & \multicolumn{2}{|c|}{$\begin{array}{l}95 \% \text { Confidence Interval of the } \\
\text { Difference }\end{array}$} \\
\hline & & & & & Lower & Upper \\
\hline Index of Loan Grants & -.737 & 7 & .485 & -.08323 & -.3502 & .1837 \\
\hline
\end{tabular}

The result on Table 10 showed a probability value of 0.485 level of significance. Since the probability value is greater than 0.05 , the null hypothesis that IFRS adoption does not significantly affects loan grants of banks in

Nigeria is not rejected. 


\section{Effect of IFRS adoption affect market value of banks}

Research Four: - To what extent does IFRS adoption affects market value of banks in Nigeria?

Table 11: Significant Effect of IFRS Adoption on market value of Banks

\section{One-Sample Statistics}

\begin{tabular}{|l|l|l|l|l|}
\hline & $\mathrm{N}$ & Mean & Std. Deviation & Std. Error Mean \\
\hline Index of Market Value & 8 & 1.8717 & 1.13465 & .40116 \\
\hline
\end{tabular}

The result of the mean comparability index on Table 11 for market value is 1.8717 . Since the mean value is greater than 1, it means that market value before NGAAP is greater than market value in the IFRS era. This implies that IFRS adoption negatively affected the market value.

Hypothesis Four - IFRS adoption does not significantly affects market value of banks in Nigeria.

Table 12: Significant Effect of IFRS Adoption on market value of Banks

\section{One-Sample Test}

\begin{tabular}{|l|l|l|l|l|l|l|}
\hline & \multicolumn{2}{|l|}{ Test Value =1 } \\
\cline { 2 - 7 } & & & Df & Sig. (2-tailed) & $\begin{array}{l}\text { Mean } \\
\text { Difference }\end{array}$ & \multicolumn{2}{l|}{$\begin{array}{l}\text { 95\% Confidence Interval of the } \\
\text { Difference }\end{array}$} \\
\cline { 5 - 8 } & & & Lower & Upper \\
\hline $\begin{array}{l}\text { Index of Market } \\
\text { Value }\end{array}$ & 2.173 & 7 & .066 & .87166 & -.0769 & 1.8203 \\
\hline
\end{tabular}

The result on Table 12 showed a probability value of 0.066 . Since the probability value is greater than 0.05 , the null that IFRS adoption does not significantly affects market value of banks in Nigeria is not rejected.

\section{Discussion of Findings}

The study showed that the introduction of IFRS reduced the profitability of banks but it does not have significant effect on the profitability of the banks in Nigeria. This suggests that the value of the profitability was lower when reported using the IFRS accounting guidelines. This implies that IFRS introduction brought about a negligible fall in bank profit. Therefore it can be said that the financial reports of banks give relatively the same information in both formats: IFRS and GAAP. Hence, the use of IFRS did not disrupt financial position of the banks. This study countered the Jensen's (2001) Value Maximisation Theory wherein firms can use one accounting principles or guidelines to maximise shareholders wealth. The present study contend that firms will not benefit from the use varying accounting principles at different accounting periods. The finding is in agreement with previous findings in Nigeria. As this study found reduced financial health for Nigerian banks (low profit, liquidity and market value and higher loan figure), the previous study agreed that IFRS means minimal earnings management and timely recognition of losses (Ugbede, Mohd \& Ahmad, 2014; Eneje, Obidike \& Chukwujekwu, 2016). In these cases, IFRS adoption have enthroned credible financial statements (Okoye, Okoye \& Ezejiofor, 2014).

Furthermore, the introduction of IFRS reduced the liquidity of banks but it does not have significant effect on the liquidity of the banks in Nigeria. This advocates the level of bank liquidity will relatively the same as in IFRS financial report in 2012 as in NGAAP report of 2011. The liquidity position of the banks in Nigeria was not influenced by the 2012 IFRS adoption. As liquidity is one bank variable that aids the bank in meeting its obligations of demand deposit and loan grants, it is notable that the introduction of IFRS did not cause liquidity problem to the banks.

More so, the introduction of IFRS increased the loan grants of banks but it does not have significant effect on the loan grants of the banks in Nigeria. This 
indicates that IFRS adoption did not alter the financial positions of the bank loan reported in financial statements. Loan grant from banks reflects their level of financial intermediation. As bank loan increased with introduction of IFRS (though not significant) bank financial intermediation is expected to improve. This disagreed with the Jensen's (2001) Value Maximisation Theory. This connotes that banks cannot gain improved financial position on bank loans by changing from NGAAP to IFRS.

Finally, the introduction of IFRS reduced the market value of banks but it does not have significant effect on the market value of the banks in Nigeria. This suggests that NGAAP and IFRS reports on the financial position of the banks in Nigeria is not far from each other. This disproved the assertion of the Jensen's (2001) Value Maximisation Theory wherein firms can use one accounting principles or guidelines to maximise shareholders wealth. Thus, it is proven that the use of IFRS did not alter the market value of banks. In total contrast to the present study was the findings IFRS adoption has positively impacted some variables in the financial statement of banks, for example, profitability and growth potential (Yahaya, Yusuf \& Dania, 2015). This study posits that IFRS results in higher reportage for bank profit as against the findings of the present study. The position of this study aligns with the view of a selected empirical works in Nigeria. As this study found reduced financial health for Nigerian banks (low profit, liquidity and market value and higher loan figure), the previous study agreed that IFRS means minimal earnings management and timely recognition of losses (Ugbede, Mohd \& Ahmad, 2014; Eneje, Obidike \& Chukwujekwu, 2016). In these cases, IFRS adoption have enthroned credible financial statements (Okoye, Okoye \& Ezejiofor, 2014).

\section{CONCLUSION AND RECOMMENDATIONS}

The comparability indices reported from the study has shown that the sampled banks have a slightly higher mean values indicating that bank performance under GAAP appeared higher than after the adoption of the IFRS. However, these higher mean values does not have overall significant impact on the banks' performance. This means that banks performance is not affected by the introduction of IFRS in Nigeria. The study has shown that Nigerian environments can easily assimilated the introduction of the IFRS in the banking system. The reduced financial health for
Nigerian banks (low profit, liquidity and market value and higher loan figure) connotes that IFRS means minimal earnings management and timely recognition of losses.

Since the adoption of IFRS did not alter bank profit, liquidity, loan and market value, reported in the subsequent year, it is recommended that banks and other quoted firms be encouraged to adopt IFRS in their financial statement. The need for uniformity in financial reporting will aid comparison of financial information across countries and encourage foreign investment. Since market value of the banks were not affected by IFRS adoption, quoted firms should be encouraged to adopt IFRS in their financial reporting. Again. the Financial Reporting Council and the various professional bodies in Nigeria should place more emphases on continuing professional education and training. As much as possible, the professional accountancy bodies should align their continuing professional education requirements with IFRS guidelines.

\section{REFERENCES}

1. Abata, M.A. (2015a). The impact of international financial reporting standards (IFRS) adoption on financial reporting practice in the Nigerian banking sector.Journal of Policy and Development Studies, (9)2, 169-184.

2. Abata, M. A. (2015b). Impact of IFRS on financial reporting practices in Nigeria (A case of KPMG). Global Journal of Contemporary Research in Accounting, Auditing and Business Ethics (GJCRA), 1(1), 263-281.

3. Abdul-Baki Z., Uthman, A. B., \& Sanni, M. (2014). Financial ratio as performance of IFRS and Nigerian GAAP. Accounting and Management Information System, 13(1), 82-97.

4. Access Bank Plc, (2010). The Implication of IFRS adoption. A Communiqué of Business Day, 9 (186), 34-37.

5. Adebimpe, O.U. \& Ekwere, R.E. (2015). IFRS adoption and value relevance of financial statements of Nigerian listed banks. International Journal of Finance and Accounting, 4(1), 1-7.

6. Akhidime A. E. (2010). The adoption and implementation of international financial accounting reporting standards (IFRS): Evaluation of the roles of key stakeholders in Nigeria. $A A U$ $J M S, 1(1), 55-60$. 
International Journal of Trend in Scientific Research and Development (IJTSRD) ISSN: 2456-6470

7. Akinleye, G.T. (2016) Effect of international financial reporting standards (IFRS) adoption on the performance of money deposit banks in Nigeria.European Journal of Business, Economics and Accountancy, 4(4), 87-95.

8. Akiwi (2010). Adoption of international financial reporting standards in developing countries - The case of Ghana. Business Economics and Tourism. VAASA Ammatikorkeakoulu University of Applied Sciences Bachelor of Business Administration.

9. Armstrong, C., Barth, M. Jagolinzer, \& A. Riedl, E., (2007). Market reaction to the adoption of IFRS in Europe. Working paper, Stanford University.

10. Asian A. U. \&Dike, A. (2015).IFRS adoption and accounting quality of quoted manufacturing firms in Nigeria: a cross sectional study of brewery and cement manufacturing firms. International Journal of Business and Management Review, 3(6), 61-77.

11. Barth, M. (2008).Global Financial Reporting, Implications for US Academics. The Accounting Review. 83(5), 1159-1179.

12. Barth, M., Landsman, W. \& Lang, M. (2007).International Accounting Standards and Accounting Quality. Journal of Accounting Research, 46,467-728.

13. Bartov, E. Goldberg, S. \& Kim M. (2005).Comparative Value Relevance among German, US and International Accounting Standards. A German stock Market perspective. Journal of Accounting, Auditing and Finance, 20, 95-119.

14. Chen, H., Tang, Q., Jiang, Y. \& Lin, Z. (2010).The Role of International Financial Reporting Standards in Accounting Quality: Evidence from the European Union. Journal of International Financial Management and Accounting 21(3), 220-278.

15. Eneje, B., Obidike, C \& Chukwujekwu, P. (2016). The Effect of IFRS Adoption on the Mechanics of Loan Loss Provisioning For Nigerian Banks. IOSR Journal of Business and Management, 18(6), 45-52.

16. Ezeani N. S. \& Oladele R. (2012). Adoption of international financial reporting standards (IFRS) to enhance financial reporting in Nigeria universities. Arabian Journal of Business and Management Review (OMAN Chapter) 2(3), 113226.

17. Frank, W. \& Alan, S. (2008). Business accounting 2. (11th ed). England: Pearson Education Limited.
18. Ironkwe, U. I. \& Oglekwu, M. (2016). International Financial Reporting Standards (IFRSs) and Corporate Performance of Listed Companies in Nigeria. IIARD International Journal of Banking and Finance Research, (2)3, $1-13$.

19. Isenmila, P. A. \& Adeyemo, K. A. (2013). A Perception Based Analysis of the Mandatory Adoption of International Financial Reporting Standards (IFRS) in Nigeria. Journal of Emerging Trends in Economics and Management Sciences (JETEMS) 4(2), 203-210.

20. Ismaila, M. Z. (2010). IFRS as a tool for cross Border Financial Reporting. International Financial Reporting Standards. Nigeria: Hazi publishers.

21. Jonathan A. Okunbor1 \& Amos O. Arowoshegbe (2014) stakeholders' perception of the adoption of IFRS in Nigeria. Accounting and Finance Research, 3(1), 67-72.

22. Kaaya, I.D. (2015). The Impact of International Financial Reporting Standards (IFRS) on Earnings Management: A Review of Empirical Evidence. Journal of Finance and Accounting, (3)3, 57-65.

23. Kenneth E. O. (2012). Adoption of IFRS and Financial / Statements Effects: The Perceived Implications on FDI and Nigeria Economy; Australian Journal of Business and Management Research, 2(5), 76-83.

24. Muhammad, T. (2012). The effect of International Financial Reporting Standards (IFRS) adoption on the performance of firms in Nigeria. Journal of Administrative and Economic Sciences Qassim University, 5(2), 133-157.

25. Muhibudeen, L. (2015). International Financial Reporting Standard and Value Relevance of Accounting Information in Quoted Cement Firms in Nigeria. International Journal of Sciences: Basic and Applied Research (IJSBAR), 22(1), 8195.

26. Mutai, B.K. (2014). The effect of adoption of international financial reporting standards on quality of financial reporting by companies listed at Nairobi Securities Exchange. A research proposal submitted in partial fulfilment of the requirement for the a ward of Master of Business Administration, School of Business, University of Nairobi. 1-45.

27. Nengzih (2015). The Adoption of IFRS - Impact on Profitability Rate and Tax Income: Evidence from Companies Indonesia Listed in Indonesian 
Stock Exchange. Research Journal of Finance and Accounting, 6(11), 174-181.

28. Nobes, C.(2006). The survival of international differences under IFRS: Towards a research agenda. Accounting and Business Research. (36), 233-245.

29. Ofurum, C.O., Egbe, S. and Micah, L.C.(2014). Corporate financial accounting \& reporting. Port Harcourt, Nigeria: Davidstones Global Resource Ltd.

30. Okoye, P.V.C., Okoye, J. F. N. \& Ezejiofor, R.A. (2014). Investigated the impact of the IFRS adoption on stock market movement in Nigerian corporate organization. International Journal of Academic Research in Business and Social Sciences, 4(9), 202-218.

31. Sani S. \& Umar D. (2014). An assessment of compliance with ifrs framework at first-time adoption by the quoted banks in Nigeria. Journal of Finance and Accounting, 2(3), 64-73.

32. Shehu, U.H. (2015). Adoption of international financial reporting standards and earnings quality in listed deposit money banks in Nigeria. Procedia Economics and Finance, 28, 92-101.

33. Singh, R. \& Newberry, S., (2008).Corporate governance and international financial reporting standard (IFRS): The case of developing countries. Research in Accounting in Emerging Economies, 8, 483-518.

34. Sofia Santos (2015). The Role of Ethical Finance in the Wellbeing of the 21st Century Societies.

35. Taiwo, F. H., \& Adejare, A. T. (2014). Empirical analysis of the effect of international financial reporting standards (IFRS) adoption on accounting practices in Nigeria. Archives of Business Research, 2(2), 1-14.

36. Ugbede O., Mohd L. \& Ahmad K. (2014). International Financial Reporting Standards and the quality of banks financial statement information: evidence from an emerging marketNigeria. European Journal of Business and Social Sciences, 3(8), 243 - 255.

37. Wilson, E.H. \& Ioraver, N.T. (2013). Economic consequences of international financial reporting standards (IFRS) adoption: Evidence from a developing country, (5), 28.1

38. Yahaya, O.A., Yusuf, M.J. and Dania, I.S. (2015). International financial reporting standards' adoption and financial statement effects: Evidence from listed deposit money banks in Nigeria, Research Journal of Finance and Accounting, 6(12), 107-122. 